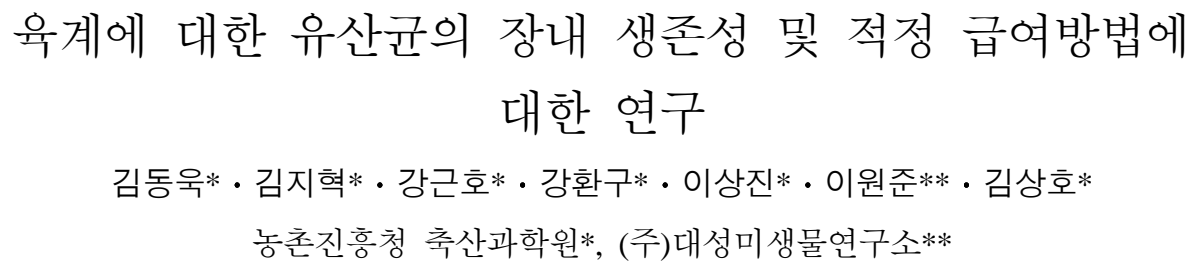

\title{
Study on Intestinal Viability and Optimum Feeding Method of Lactobacillus in Broiler Chickens
}

\author{
Dong Wook Kim*, Ji Hyuk Kim*, Geun Ho Kang*, Hwan Ku Kang*, Sang Jin Lee*, Won Jun Lee** \\ and Sang Ho Kim* \\ National Institute of Animal Science, R.D.A., Korea*, \\ DaeSung Microbiological Laboratory Co., Ltd., Korea**
}

\begin{abstract}
This study was conducted to prove the optimum feeding method of Lactobacillus in broiler chickens by investigating the intestinal viability of ingested Lactobacillus and the effect of feeding levels and frequency of Lactobacillus on growth performance in broiler chickens.

In experiment 1, A total of one hundred, 5 weeks old male broiler chickens (Abor Acre) were fed Lactobacillus reuteri avibro2 expressed green fluorescent protein (GFP) at $10^{4} \mathrm{cfu} / \mathrm{g}$ diet to investigate the retention time of ingested Lactobacillus in the intestine for 1 day. The percentage of Lactobacillus expressed GFP in intestinal contents was $26 \%$ at 1 day after fed Lactobacillus expressed GFP. The percentage of Lactobacillus expressed GFP in intestinal contents was decreased in length of time.

In experiment 2, A total of four hundred eighty, 1-d-old male broiler chicks (Abor Acre) were randomly divided into 4 groups with 4 replicates of 30 birds each to prove the optimum feeding level of Lactobacillus. The treatments were control (free antibiotics), Lactobacillus reuteri avibro $25.0 \times 10 \mathrm{cfu} / \mathrm{mL}$, $5.0 \times 10^{3} \mathrm{cfu} / \mathrm{mL}$, and $5.0 \times 10^{5} \mathrm{cfu} / \mathrm{mL}$. The final body weight and body wight gain of Lactobacillus reuteri avibro2 $5.0 \times 10^{3} \mathrm{cfu} / \mathrm{mL}$ were the highest in all groups $(\mathrm{P}<0.05)$. Feed conversion ratio was not significantly difference among the groups. The number of intestinal lactic acid bacteria in Lactobacillus treated groups tended to be improved or significantly increased as compared to that of control $(\mathrm{P}<0.05)$. Protein and fat digestibility in Lactobacillus $5.0 \times 10^{3} \mathrm{cfu} / \mathrm{mL}$ and $5.0 \times 10^{5} \mathrm{cfu} / \mathrm{mL}$ treated groups were significantly improved $(\mathrm{P}<0.05)$. No significant differences were observed on the availability of dry matter and crude ash in Lactobacillus treatments compared to those of control.

In experiment 3, A total of six hundred 1-d-old male broiler chicks (Abor Acre) were randomly divided into 4 groups with 4 replicates of 30 birds each and were fed Lactobacillus reuteri avibro2 at intervals of $1,2,3$, and 5 day for five weeks. Feeding level of Lactobacillus was $5.0 \times 10^{3} \mathrm{cfu} / \mathrm{mL}$ The final body weight and body wight gain of Lactobacillus reuteri avibro2 $5.0 \times 10^{3} \mathrm{cfu} / \mathrm{mL}$ were the highest in all groups $(\mathrm{P}<0.05)$. The final body weight and body weight gain were significantly increased, when Lactobacillus was fed at intervals of 1 days, or 2 days. There were no significant differences in feed intake and feed conversion ratio among the all groups. The number of intestinal lactic acid bacteria in Lactobacillus treated groups tended to be improved or significantly increased as compared to that of control $(\mathrm{P}<0.05)$. No
\end{abstract}

Corresponding author : Sang Ho Kim, National Institute of Animal Science, R.D.A, Korea Tel : 041-580-6709, Fax : 041-580-6719, E-mail : shkim@rda.go.kr 
significant differences were observed on the number of coliform bacteria and Salmonella of ileum and cecum.

Consequently, supplemental Lactobacillus influenced positive effects on the growth performance, nutrient availability and intestinal microflora. The optimum feeding level of Lactobacillus was $5.0 \times 10^{3} \mathrm{cfu} / \mathrm{mL}$, and the constant feeding of Lactobacillus was effective.

(Key words : Lactobacillus, Broiler, Growth performance, Digestibility, Intestinal microflora)

\section{I. 서 론}

가축 사료 내 항생제는 가축의 성장 촉진 및 질병 발생 감소를 통해 대규모의 집약적 축산 을 가능하게 하였으며 가금 산업에 있어서도 생산성 및 사료 이용율을 3 5\% 이상 향상시켰 다 (Pirgozliev 등, 2007). 그러나 최근 내성균 출 현, 축산물 내 항생제 잔류 등의 문제가 대두 되면서 성장촉진용 항생제의 사용에 대한 제한 및 규제가 강화되고 있다. 또한 수입 축산물에 대한 경쟁력 제고 및 소비자의 안전 축산물에 대한 요구에 따라 무항생제 사육에 대한 관심 역시 높아지고 있다. 이에 따라 무항생제 사육 시 발생하는 생산 비용 증가, 가축 생산성 저 하, 질병 발생율 및 폐사율 증가 등의 문제를 최소화하기 위해 새로운 사양 프로그램 개발 및 항생제 대체제 개발 등의 연구가 요구되고 있다.

현재 생균제, 효소제, 식물추출물, 면역증강 제 등 다양한 종류의 항생제 대체제가 개발, 사용되고 있으며, 이 가운데 생균제는 장내 미 생물의 균형을 개선함으로서 숙주 동물에 유익 한 영향을 주는 살아있는 미생물을 말한다 (Fuller, 1989; Gibson과 Fuller, 2000). 생균제로 많이 이용되고 있는 미생물은 Lactobacillus속, Streptococcus속, Bifidobacterium속, 유포자 유산 균인 Bacillus속 및 효모 등이 있으며 (Bongaerts, 2005), 이 중 유산균은 그람 양성균으로서 형태 적, 대사적, 생리적 특성에 따라 Lactobacillus, Lueconostoc, Pediococcus 및 Enterococcus 속으 로 분류된다. Fuller (1989) 및 Jin 등 (1996)은 유 산균 첨가 급여시 증체량 및 사료요구율 등 육 계 생산성이 개선되었다고 보고하였으며, Impey 와 Mead(1989)는 유산균은 장점막 상피세포에 부착, 서식하면서 영양소의 분해와 흡수를 돕 고 경쟁적 배제를 통해 병원성 미생물의 집락
화를 억제하여 상피세포를 보호하는 역할을 수 행한다고 하였다. 일반적으로 유산균은 E. coli, Salmonella 및 Campylobacter 등 유해균의 서식 및 증식을 억제하여 장질환 및 내인성 질병을 감소시킨다 (Fuller, 1989; Gibson과 Fuller, 2000). 또한 유산균의 대사과정에서 생산되는 효소 등 의 대사물질이 점막세포의 분화 및 성숙을 증 가시켜 (Smith, 1985) 영양소 이용율 개선 및 장 관 면역 발달에 관여하여 가축의 생산성 및 면 역 능력을 향상시킬 수 있다고 보고되어 왔다 (Mohan 등, 1996; Watkins 등, 1982; Watkins와 Kratzer, 1983). 그러나 모든 유산균이 항상 동 일한 효과를 나타내지는 않은데, 이러한 원인 으로는 유산균의 생균제적 가치 차이(Jin 등, 1998), 적정 균수의 미공급 (박수영 등, 2001; 김상호 등, 2000) 및 닭이 받는 스트레스 정도 의 차이 (Lyons, 1987)를 들 수 있다. 가금에서 장내 미생물 균총은 부화 후 1 주일 내에 확립 되기 때문에 부화 초기부터 생균제를 급여하는 것이 장관 미생물 균총 안정화에 효과적이며 (Jin 등, 1996), 유산균 및 생균제의 효율적인 급여량 및 급여 방법에 대한 자료는 극히 제한 적이지만 일반적으로 분내 미생물의 경우 사료 $\mathrm{g}$ 당 $10^{6} \sim 10^{7}$ 정도가 적당한 것으로 알려져 있 다. 사육 환경, 사료 조성, 급여되는 유산균의 종류 및 급여시기에 따라 적정 생균수, 급여기 간 및 방법 등을 달리하여야 하나 이에 대한 연구가 부족한 실정이다.

따라서 본 시험은 외인성 유산균의 장내 체 류 시간을 파악하고, 육계 맹장에서 분리한 Lactobacillus reuteri avibro2의 첨가수준 및 급 여 빈도에 따른 육계 생산성, 장내 미생물 균 총 및 영양소 이용율에 미치는 영향을 조사하 여 적정 첨가수준 및 급여빈도를 구명하기 위 하여 수행되었다. 


\section{ㅍ. 재료 및 방법}

시험 1. 외인성 유산균의 장내 생존성 및 체 류 시간 조사

해파리의 일종인 Acquoria victoria에서 발현 되는 238개의 아미노산으로 구성된 형광단백질 인 green fluorescent protein (GFP) 발현 유전자 를 유산균용 발현 vector인 pKU::slpA-GFP를 이 용하여 육계 맹장에서 분리한 Lactobacillus reuteri avibro2(KFCC-11195)에 형질전환시켰다 (김세헌 등, 2006). 형광 현미경 (Olympus BX51, Olympus Optical Co., Ltd., Japan)을 이용하여 유산균의 GFP 발현 여부를 검증하였다 (Fig. 1). 이와 같이 형질전환된 유산균을 5 주령 육계 (Abor Acre) 100 수에게 사료 내 $1.0 \times 10^{4} \mathrm{cfu} / \mathrm{g}$ 수 준으로 첨가 급여하였다. 급여 후 1 일, 3 일, 5 일 및 7일차에 5수씩 희생시켜 회장 점막 조직 및 장 내용물을 채취하였다. 채취된 조직은 2.5\% glutaraldehyde로 전고정하고 인산완충액으 로 세척한 후 $1 \%$ osmiumtetroxide에 후고정하였 다. 에탄올을 이용하여 탈수하고 isoamyl acetate 로 치환한 후 hexamethyl-disilazane으로 건조시 킨 다음 gold sputter coater (Ladd 30800, Ladd Research Industries Inc., America)로 도금하여 주 사 전자현미경(JSM-5310LV, Japan Electron Optics Laboratory Co., Ltd., Japan)으로 관찰하 고 촬영하였다. 채취된 장 내용물은 생리식염
수로 $10^{-9}$ 까지 단계별로 희석하여 Rogosa agar (Difco, USA) 평판 배지에 접종하였다. $\mathrm{CO}_{2}$ incubator (Forma 311, Forma Scientific Inc., USA)를 이용하여 혐기적 조건에서 48시간 배 양한 후 형광 현미경으로 GFP가 발현된 유산 균 수를 계수하였다.

\section{시험 2. 음수 내 유산균의 첨가수준에 따른} 육계 생산성 변화

\section{1. 시험동물 및 시험설계}

시험 2에서는 유산균 적정 첨가 수준을 구명 하기 위하여 1 일령 육계 수평아리 (Abor Acre) 480수를 공시하여 4처리 4반복, 반복당 30수씩 임의 배치하여 5주간 사양시험을 실시하였다. 시험처리는 항생제 무첨가구를 대조구로 하였 으며, 음수 내 유산균을 $5.0 \times 10 \mathrm{cfu} / \mathrm{mL}, 5.0 \times 10^{3}$ $\mathrm{cfu} / \mathrm{mL}$, 및 $5.0 \times 10^{5} \mathrm{cfu} / \mathrm{mL}$ 수준으로 첨가하여 유산균 처리구를 두었다.

\section{2. 공시균주, 시험사료 및 사양관리}

육계 맹장에서 분리한 Lactobacillus reuteri avibro2 (KFCC-11195)를 사용하였다. 시험사료 는 NRC(1994)에 근거하여 단백질과 에너지 함 량을 동일하게 배합하였으며, 육계전기 (0 3주) 와 육계후기 (3 5주) 사료로 나누어 공급하였다.
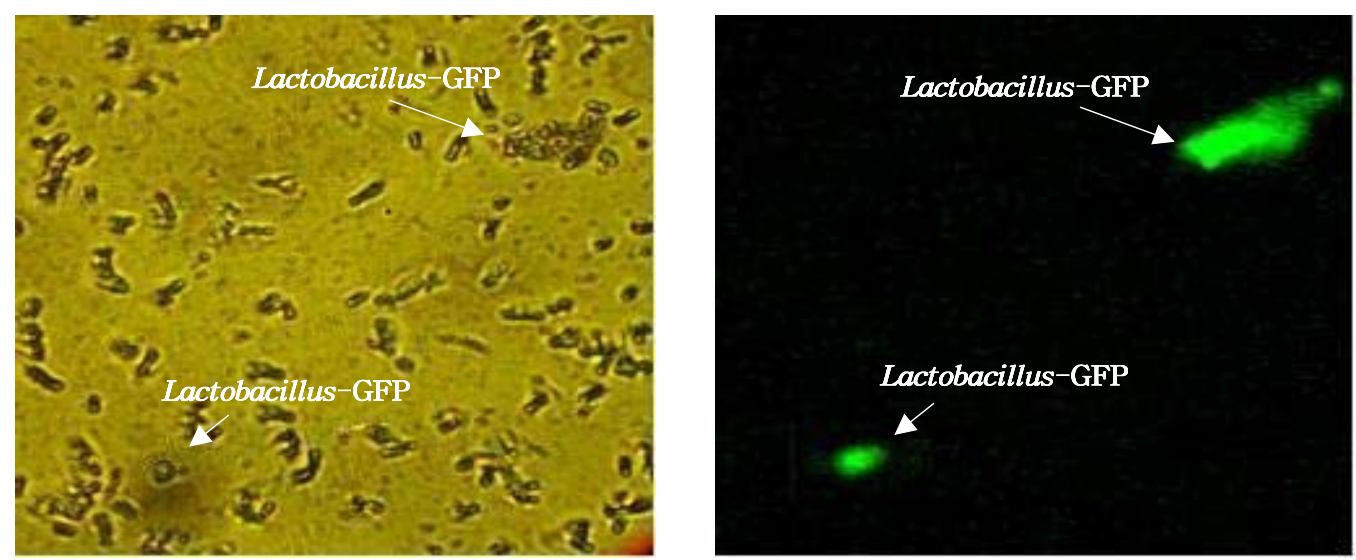

Fig. 1. Confirmation of GFP expression of Lactobacillus transformated by pKU::s/pA-GFP under fluorescence microscopy. 
시험사료의 배합비 및 영양소 조성은 Table 1 에 나타내었다. 사양 실험 전 기간동안 평사에 서 사육하였으며 사료 급이기 및 급수기의 개 수는 반복구별 동일하게 배치하였다. 사료와 물은 자유 채식 및 자유 음수 시켰으며, 입추 후 3일간 24시간 점등을 실시하였고 이후 7일 령까지 23시간 점등을 실시하였다. 8일령부터 시험 종료시까지 야간간헐점등( $1 \mathrm{~L}: 2 \mathrm{D})$ 을 실시 하였다.

Table 1. Formula and chemical composition of the basal diet in Experiments 1 to 3

\begin{tabular}{|c|c|c|}
\hline & $\begin{array}{c}\text { Starter } \\
(0 \sim 3 w \mathrm{k})\end{array}$ & $\begin{array}{l}\text { Finisher } \\
(3 \sim 5 w k)\end{array}$ \\
\hline & \multicolumn{2}{|c|}{ …....... \% } \\
\hline Corn & 53.44 & 61.64 \\
\hline Soybean Meal & 33.65 & 27.88 \\
\hline Corn Gluten Meal & 4.16 & 4.00 \\
\hline Soybean oil & 4.68 & 3.06 \\
\hline Limestone & 1.02 & 1.23 \\
\hline Tricalcium phosphate & 2.01 & 1.31 \\
\hline Salt & 0.25 & 0.25 \\
\hline DL-Methionine & 0.27 & 0.08 \\
\hline Lysin-HCl & 0.02 & 0.05 \\
\hline Vitamin-mineral mixture $^{1)}$ & 0.50 & 0.50 \\
\hline Total & 100.0 & 100.0 \\
\hline \multicolumn{3}{|l|}{ Calculated value } \\
\hline ME, kcal/kg & 3,100 & 3,100 \\
\hline Crude Protein, \% & 22.0 & 20.0 \\
\hline Methionine, \% & 0.50 & 0.38 \\
\hline Lysine, \% & 1.10 & 1.00 \\
\hline Ca, \% & 1.00 & 0.90 \\
\hline Available P, \% & 0.50 & 0.35 \\
\hline \multicolumn{3}{|c|}{$\begin{array}{l}\text { 1) Vitamin-mineral mixture provided following } \\
\text { nutrients per kg of diet: } \\
\text { vitamin A, } 15,000 \mathrm{IU} \text {; vitamin } \mathrm{D}_{3}, \quad 1,500 \mathrm{IU} \text {; } \\
\text { vitamin E, } 20.0 \mathrm{mg} \text {; vitamin } \mathrm{K}_{3}, 0.70 \mathrm{mg} \text {; vitamin } \\
\mathrm{B}_{12}, 0.02 \mathrm{mg} \text { niacin, } 22.5 \mathrm{mg} ; \text { thiamin, } 5.0 \mathrm{mg} \text {; } \\
\text { folic acid, } 0.70 \mathrm{mg} \text {; pyridoxin, } 1.3 \mathrm{mg} \text {; riboflavin, } 5 \\
\text { mg; pantothenic acid, } 25 \mathrm{mg} \text {; choline chloride, } 175 \\
\text { mg; Mn, } 60 \mathrm{mg} \text {; Zn, } 45 \mathrm{mg} \text { I, } 1.25 \mathrm{mg} \text {; } \mathrm{Cu}, 10.0 \\
\text { mg; Fe, } 72 \mathrm{mg} \text {; Co, } 2.5 \mathrm{mg} \text {. }\end{array}$} \\
\hline
\end{tabular}

\section{3. 조사항목}

\section{(1) 육계 생산성}

시험 종료시 체중을 측정하여 개체별 증체량 을 산출하였으며, 사료섭취량은 전기 (0 3주), 후기 (3 5주) 반복별로 사료잔량을 측정하여 섭 취량을 구하였다. 조사된 사료섭취량과 증체량 을 통해 사료요구율을 산출하였다.

\section{(2) 회장 및 맹장 내 유산균 변화}

장내 유산균수의 변화를 조사하기 위해서 시 험 종료시 생체중의 평균 범위에 해당하는 개 체를 처리구별 5수씩 희생시켜 회장 및 맹장 내용물을 채취하였다. 회장 내용물은 Meckel's diverticulum 부위에서 아래쪽으로 $5 \mathrm{~cm}$ 정도 절 단하여 채취하였으며, 맹장 내용물은 양쪽 맹 장의 내용물을 혼합하여 사용하였다. 유산균의 수를 측정하기 위해 채취된 회장 및 맹장 내용 물을 생리식염수로 $10^{-9}$ 까지 단계별로 희석하 였으며, 이렇게 희석된 내용물을 Rogosa agar (Difco, USA) 평판 배지에 접종하였다. $\mathrm{CO}_{2}$ incubator (Forma 311, Forma Scientific Inc., USA)를 이용하여 혐기적 조건에서 48시간 배 양한 후 균수를 측정하여 내용물 $1 \mathrm{~g}$ 당 $\mathrm{cfu}$ (colony forming unit)로 계산한 후 $\log _{10}$ 으로 환 산 표기하였다.

\section{(3) 영양소 이용율}

영양소 이용률을 조사하기 위하여 사양시험 종료 후 평균 체중 범위에 속하는 개체를 처리 당 5수씩 선발하여 대사케이지로 옮겨 3일 동 안 전분을 채취하였다. 채취된 전분을 $60^{\circ} \mathrm{C}$ 송 풍건조기 (J-300S, JISICO, Korea)에서 건조시킨 후 분쇄하여 시료로 이용하였다. 일반성분은 AOAC 방법 (1995)을 기초로 하여 측정하였다. 각 영양소 이용률은 아래 공식을 이용하여 계 산하였다.

\footnotetext{
영양소 이용률(\%, 건물기준) $=$

(총섭취량 $\times$ 사료 영양소 함량)(총배설량 $\times$ 분뇨 영양소 함량) $\times 100$

(총섭취량 $\times$ 사료 영양소 함량)
} 
시험 3. 음수 내 유산균의 급여 빈도에 따른 육계 생산성 변화

\section{1. 시험동물 및 시험설계}

시험 3에서는 유산균 적정 급여 빈도를 구명 하기 위하여 1 일령 육계 수평아리 (Abor Acre) 600 수를 공시하여 5처리 4반복, 반복당 30수씩 임의 배치하여 5 주간 사양시험을 실시하였다. 시험처리는 항생제 무첨가구를 대조구로 하였 으며, 유산균이 $5.0 \times 10^{3} \mathrm{cfu} / \mathrm{mL}$ 수준으로 첨가된 음수를 1일, 2일, 3일 및 5일 간격으로 급여한 유산균 처리구를 두었다.

\section{2. 공시균주, 시험사료 및 사양관리}

시험 2에서 동일한 유산균인 Lactobacillus reuteri avibro2 (KFCC-11195)를 사용하였다. 시 험사료는 NRC(1994)에 근거하여 단백질과 에 너지 함량을 동일하게 배합하였으며, 육계전기 (0 3주)와 육계후기 (3 5주) 사료로 나누어 공급 하였다. 시험사료의 배합비 및 영양소 조성은 시험 2와 동일하게 하였다(Table 1). 사양 실험 전 기간동안 평사에서 사육하였으며 사료 급이 기 및 급수기의 개수는 반복구별 동일하게 배 치하였다. 사료와 물은 자유 채식 및 자유 음 수 시켰으며, 입추 후 3일간 24시간 점등을 실 시하였고 이후 7일령까지 23시간 점등을 실시 하였다. 8일령부터 시험 종료시까지 야간간헐 점등(1L:2D)을 실시하였다.

\section{3. 조사항목}

\section{(1) 육계 생산성}

시험 종료시 체중을 측정하여 개체별 증체량 을 산출하였으며, 사료섭취량은 전기( $0 \sim 3$ 주), 후기(3 -5주) 반복별로 사료잔량을 측정하여 섭 취량을 구하였다. 조사된 사료섭취량과 증체량 을 통해 사료요구율을 산출하였다.

(2) 장내 미생물 균총 변화 장내 유산균수의 변화를 조사하기 위해서 시
험 종료시 생체중의 평균 범위에 해당하는 개 체를 처리구별 5수씩 희생시켜 회장 및 맹장 내용물을 채취하였다. 회장 내용물은 Meckel's diverticulum 부위에서 아래쪽으로 $5 \mathrm{~cm}$ 정도 절 단하여 채취하였으며, 양쪽 맹장의 내용물을 혼합하여 사용하였으며, 채취된 맹장 내용물은 생리식염수로 $10^{-9}$ 까지 단계별로 희석하였다. 이렇게 희석된 내용물을 SS agar(Salmonella spp), MacConkey agar(Coliform bacteria) 및 Rogosa agar (Lactic acid bacteria) 평판배지에 각 각 접종하였다. Lactic acid bacteria는 혐기적으 로 나머지는 호기적 조건에서 24시간 배양한 후 균수를 측정하여 내용물 $1 \mathrm{~g}$ 당 cfu(colony forming unit)로 계산한 후 $\log _{10}$ 으로 환산 표기 하였다.

\section{4. 통계처리}

실험에서 얻어진 모든 결과는 Statistical Analysis System (SAS release ver 9.1, 2002)의 General Linear Model procedure를 이용하여 분 산분석을 실시하였고, 처리구간에 유의성은 Duncan's multiple range-test (Duncan, 1955)를 이 용하여 $5 \%$ 수준에서 검정하였다.

\section{III. 결과 및 고찰}

시험 1. 외인성 유산균의 장내 생존성 및 체 류 시간 조사

회장 점막을 전자현미경으로 촬영하여 $\mathrm{GFP}$ 유산균이 점막에 부착되어 있는 것을 확인하였 으며(Fig. 2), 장 내용물 내 GFP 유산균의 비율 을 조사하여 외인성 유산균의 장내 체류 시간 을 Fig. 3에 나타내었다. 급여 후 1 일차 GFP 삽 입 유산균은 전체 유산균의 $26 \%$ 정도를 차지 하였다. 3일차까지 완만한 감소를 보였고 일정 수 이상 관찰되었으나, 이후 급격히 감소하여 7일 후에는 거의 관찰되지 않았다.

유산균이 생균제로 이용되기 위해서는 비병 원성, 상피 및 점막 부착 능력, 위산 및 담즙산 저항성, 장관 생존능력, 유기산 생산 능력 등 

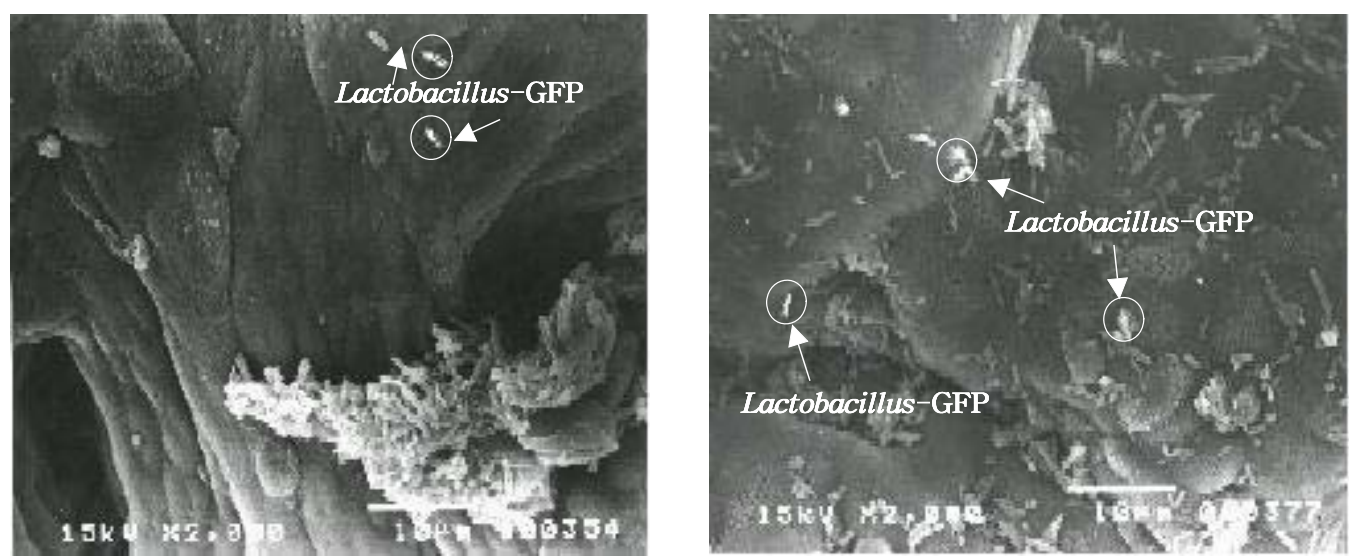

Fig. 2. Observation of the small intestine from chickens ingested with Lactobacillus expressed GFP by Electronic microscopy. Lactobacillus expressed GFP appears as a bright band close to the epithelial surface.

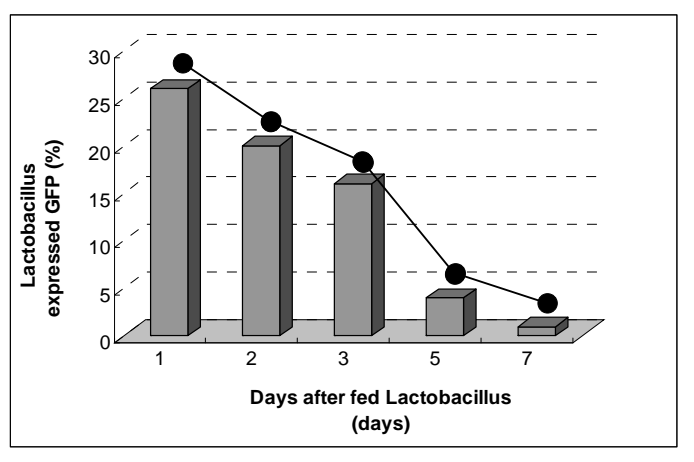

Fig. 3. Proportion of Lactobacillus expressed GFP among the intestinal lactic acid bacteria.

다양한 특성을 갖춰야 한다(Fuller, 1989; Gilliland, 1979). 특히 상피세포 및 점막 부착 능력은 유산균의 경쟁적 배제, 점막 자극을 통 한 장관 발달, 대사 물질 배출 등의 기능을 원 활히 수행하기 위한 중요한 특성으로 숙주 동 물 특이성 차이에 의해 결정되는 것으로 알려 져 있다(Fuller, 1989; Impey와 Mead, 1989). Fuller (1975)는 가금에서 분리되지 않은 유산균 은 닭 소낭에 부착하지 못 하였다고 보고하였 으며, Jin 등 (1996)은 in vitro 시험을 통해 닭의 소화기관에서 분리한 유산균은 닭의 회장벽에 부착하는 능력을 가지고 있다고 보고하였다. 본 시험에서 사용한 Lactobacillus reuteri avibro2 는 육계 맹장에서 분리, 동정한 유산균으로서
토양, 식물 및 타 축종 유래 미생물에 비해 적 응력 및 부착능력이 우수할 것으로 기대하였으 나 장관 내에서 증식하지 못하고 7일 이후 모 두 배설되는 것을 확인할 수 있었다. 그러나 외인성 유산균의 장내 부착 및 서식 여부는 사 료의 종류, 숙주동물의 나이 및 이미 확립된 미생물 균총에 영향을 많이 받으며, 장관 및 장점막 발달과 장내 미생물 균총이 형성되는 초기에 효과적인 것으로 알려져 있다(Fuller, 1989; Jin 등, 1996). 본 시험은 장점막 발달 및 장내 미생물 균총 형성이 이미 이루어진 5주령 육계를 대상으로 한 것이고 지속적으로 급여한 것이 아니라 1 일 동안 급여한 후 조사한 것이 기 때문에 본 시험 결과만으로 Lactobacillus reuteri avibro2의 부착 및 증식 가능 여부를 판 단하기에는 어려움이 있다고 사료된다.

\section{시험 2. 음수 내 유산균의 첨가수준에 따른 육계 생산성 변화}

(1) 육계 생산성

유산균 첨가수준별 육계 생산성에 미치는 영 향은 Table 2에 나타낸 바와 같다. 종료체중은 유산균 $5.0 \times 10^{3} \mathrm{cfu} / \mathrm{mL}$ 첨가시 $1,919 \mathrm{~g}$ 으로 가장 높았으며 $(\mathrm{P}<0.05)$, 육계 전기 생산성에 있어서 는 처리구간 차이가 관찰되지 않았으나, 육계 후기 생산성의 경우 유산균 $5.0 \times 10^{3} \mathrm{cfu} / \mathrm{mL}$ 및 
Table 2. Effects of feeding levels of Lactobacillus on the growth performance in broiler chickens (Experiment 2)

\begin{tabular}{cccccc}
\hline & \multirow{2}{*}{ Control } & \multicolumn{2}{c}{ Levels of } & Lactobacillus (cfu/ml) & \multirow{2}{*}{ SEM } \\
\cline { 3 - 4 } & & $5.0 \times 10$ & $5.0 \times 10^{3}$ & $5.0 \times 10^{5}$ & \\
\hline \hline Initial body weight (g) & 44.3 & 44.2 & 44.3 & 43.8 & 0.16 \\
Final body weight (g) & $1,849^{\mathrm{b}}$ & $1,869^{\mathrm{b}}$ & $1,919^{\mathrm{a}}$ & $1,880^{\mathrm{ab}}$ & 6.97 \\
\hline Body weight gain (g) & & & & \\
0-21d & 692 & 694 & 702 & 698 & 3.10 \\
22-35d & $1,133^{\mathrm{b}}$ & $1,151^{\mathrm{b}}$ & $1,193^{\mathrm{a}}$ & $1,162^{\mathrm{ab}}$ & 5.82 \\
0-35d & $1,825^{\mathrm{b}}$ & $1,845^{\mathrm{b}}$ & $1,895^{\mathrm{a}}$ & $1,856^{\mathrm{ab}}$ & 6.99 \\
\hline 0-21d & & & & \\
22-35d & 996 & 992 & 1,004 & 1,000 & 3.59 \\
0-35d & $2,092^{\mathrm{b}}$ & $2,153^{\mathrm{ab}}$ & $2,169^{\mathrm{a}}$ & $2,138^{\mathrm{ab}}$ & 10.57 \\
Feed intake (g) & 3,088 & 3,145 & 3,173 & 3,138 & 12.09 \\
22-35d & & & & \\
0-35d & 1.44 & 1.43 & 1.43 & 1.44 & 0.01 \\
\hline Feed conversion ratio & 1.85 & 1.87 & 1.82 & 1.84 & 0.01 \\
\hline
\end{tabular}

${ }^{\mathrm{a}, \mathrm{b}}$ Mean within the same row with no common superscripts differ significantly $(\mathrm{P}<0.05)$.

$5.0 \times 10^{5} \mathrm{cfu} / \mathrm{mL}$ 첨가구에 있어서 증체량 및 사료 섭취량이 대조구에 비해 증가하였다 $(\mathrm{P}<0.05)$. 사 료 요구율에 있어서는 차이가 없었다.

유산균은 장내환경 변화를 통해 E. coli 및 Salmonella 등의 병원균을 억제하여 장질환 및 내인성 질병을 감소시키고 (Fuller, 1989; Gibson과 Fuller, 2000), 장관 내에서 단백질, 비타민, 효소, 유기산 및 미지성장인자 등을 합성하며(Fuller, 1989), 영양소 소화율 개선 및 장관 면역 발달에 관여하여 가축의 생산 성 및 면역 능력을 향상시킬 수 있다고 보고 되어 왔다 (Mohan 등, 1996; Watkins와 Kratzer, 1983). Yeo와 Kim(1997)은 육계에 Lactobacillus casei를 첨가 급여한 시험에서 전기 3주령까 지는 일당 증체량이 유의적으로 증가를 했으 나 후기 4 6주령에는 유의적인 차이가 없었 다고 보고하였으며, Mohan 등 (1996) 역시 육 계에 Lactobacillus acidophilus 및 Lactobacillus casei 등이 포함된 복합 생균제 급여시 증체 량이 향상되었다고 보고하였다. 반면, Watkins 와 Kratzer (1983) 및 Maiolino 등 (1992)은 유 산균 첨가 급여에 따른 육계 생산성 향상은
관찰되지 않았다고 보고하였다. 이와 같이 유산균 및 생균제 급여시 다소 상반된 결과 를 나타내는 것은 숙주동물의 건강 상태 및 스트레스 정도, 이미 정착되어 있는 장내 미 생물 균총, 유산균의 생균제적 가치 차이 및 급여된 생균수 등 다양한 요인이 작용한다 (Jin 등, 1998; 김상호 등, 2000; 박수영 등, 2001). 유산균 및 생균제의 적정 급여 수준에 대한 자료가 극히 제한적이지만 일반적으로 사료 $\mathrm{g}$ 당 $10^{6} \sim 10^{7}$ 정도가 적당한 것으로 알 려져 있으며, 실제 시판 이용되고 있는 생균 제의 경우 보관 및 취급시 사멸하는 균과 섭 취 후 소화관을 통과하며 위산 및 담즙에 의 해 사멸하는 균을 고려하여 보다 높은 수준 으로 첨가 급여하고 있다. 본 연구 결과, 유 산균의 음수 내 첨가 급여는 육계 생산성에 긍정적인 영향을 미쳤으며 유산균 $5.0 \times 10^{3}$ $\mathrm{cfu} / \mathrm{mL}$ 첨가시 가장 효과적이었는데 유산균 의 적정 급여 수준에 있어서 다소 차이를 보 인 것은 유산균의 종류 및 음수 급여에 의한 차이인 것으로 사료된다. 
(2) 회장 및 맹장 내 유산균 변화

육계에서 유산균의 첨가급여가 회장 및 맹장 내 유산균 수에 미치는 영향은 Table 3에 제시 하였다. 첨가수준별로 차이는 있었으나 유산균 첨가 급여시 회장 및 맹장 내 유산균 수가 유 의하게 증가하였으며 $(\mathrm{P}<0.05)$ 그 변화 양상은 회장과 맹장에서 유사하게 나타났다.

유산균 및 그 배양물의 급여가 장내 미생물 에 미치는 효과에 대해서는 상이한 결과들이 보고되어 왔다. Fuller (1977)는 살아있는 미생물 의 급여는 숙주동물의 소화기관 미생물 균형을 향상시킴으로써 유익한 효과를 가져다준다고 보고하였으며, Nurmi와 Rantala (1973) 및 Jin 등 (1996)은 유산균의 첨가 급여는 장관 내 유산균 의 집락 형성 및 서식을 증가시키고, 이들이 생산하는 유기산 등의 대사산물이 장관 $\mathrm{pH}$ 등 장내 환경을 조정하여 효모 등의 유익균이 서 식, 증식하는데 긍정적인 영향을 미친다고 하 였다. 반면 Alder와 DaMass (1980)는 부화 당일 유산균을 급여하였을 때, 맹장 내 미생물 균총 에 변화가 없었다고 보고하였다. 또한 유산균 배양물의 급여시 유산균, 혐기성 미생물 등에 영향을 미치지 않았다고 보고된 바 있다(Jin 등, 1996). 이는 가축의 건강 상태 및 이미 정 착되어 있는 장내 균총 상태, 급여된 균종의
차이 및 생균수 등 다양한 요인이 작용하기 때 문이다. 본 연구 결과에서는 유산균의 첨가수 준에 따라 약간의 차이가 있긴 하였으나 전반 적으로 유산균 첨가 급여시 유산균의 수가 증 가하는 것을 확인할 수 있었다.

\section{(3) 영양소 이용율}

유산균의 첨가수준별 영양소 이용율 변화는 Table 4에서 보는 바와 같다. 음수 내 유산균 $0.5 \times 10^{4} \mathrm{cfu} / \mathrm{mL}$ 및 $0.5 \times 10^{6} \mathrm{cfu} / \mathrm{mL}$ 첨가구에 있어 서 단백질 및 지방 이용율이 유의하게 향상되 었으나 $(\mathrm{P}<0.05)$, 건물 및 조회분에 있어서는 처 리간 차이가 관찰되지 않았다.

Schneitz 등 (1998)은 건강한 성계의 맹장 내 용물에서 선발한 32종의 미생물을 혼합하여 제 조한 생균제를 육계의 사료에 첨가하였을 때, 유기물 소화율이 $1 \%$ 증가하였으며 질소의 이 용율 역시 1.5 3.0\% 증가하였다고 보고하였으 며, Nahashon 등 (1994)도 복합생균제를 산란계 에 급여한 시험에서 $4.4 \times 10^{7} \mathrm{cfu} / \mathrm{g}$ 및 $8.8 \times 10^{7}$ $\mathrm{cfu} / \mathrm{g}$ 첨가시 질소, 인 및 칼슘 이용율이 증가 하였다고 보고하였다. 유산균의 첨가 급여는 장관 내 유산균의 집락 형성 및 서식을 증가시 키고 이들이 생산하는 유기산 등의 대사산물이 장관 $\mathrm{pH}$ 를 조정하는 (Nurmi와 Rantala, 1973;

Table 3. Effects of feeding levels of Lactobacillus on the number of lactic acid bacteria in broiler chickens (Experiment 2)

\begin{tabular}{lccccc}
\hline & \multirow{2}{*}{ Control } & \multicolumn{2}{c}{ Levels of Lactobacillus $(\mathrm{cfu} / \mathrm{ml})$} & \multirow{2}{*}{ SEM } \\
\cline { 3 - 4 } & & $5.0 \times 10$ & $5.0 \times 10^{3}$ & $5.0 \times 10^{5}$ & \\
\hline \hline & & $\ldots \ldots \ldots \ldots \ldots$ & $\log 10 \mathrm{cfu} / \mathrm{g}$ content & $\ldots \ldots \ldots \ldots \ldots \ldots$ & \\
Ileum & $7.291^{\mathrm{b}}$ & $8.589^{\mathrm{ab}}$ & $9.228^{\mathrm{a}}$ & $8.864^{\mathrm{a}}$ & 0.13 \\
Cecum & $8.365^{\mathrm{b}}$ & $9.120^{\mathrm{ab}}$ & $9.584^{\mathrm{a}}$ & $9.986^{\mathrm{a}}$ & 0.20 \\
\hline
\end{tabular}

${ }^{\mathrm{a}, \mathrm{b}}$ Mean within the same row with no common superscripts differ significantly $(\mathrm{P}<0.05)$.

Table 4. Effects of feeding levels of Lactobacillus on the nutrient availability in broiler chickens (Experiment 2)

\begin{tabular}{|c|c|c|c|c|c|}
\hline & \multirow{2}{*}{ Control } & \multicolumn{3}{|c|}{ Levels of Lactobacillus (cfu/ml) } & \multirow{2}{*}{ SEM } \\
\hline & & $5.0 \times 10$ & $5.0 \times 10^{3}$ & $5.0 \times 10^{5}$ & \\
\hline & \multicolumn{5}{|c|}{ 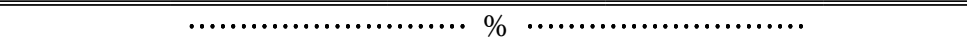 } \\
\hline Dry matter & 75.3 & 76.2 & 80.5 & 78.8 & 1.36 \\
\hline Crude protein & $66.2^{\mathrm{b}}$ & $68.4^{\mathrm{b}}$ & $72.3^{\mathrm{a}}$ & $70.2^{\mathrm{ab}}$ & 0.86 \\
\hline Crude fat & $75.3^{\mathrm{b}}$ & $76.3^{\mathrm{b}}$ & $80.6^{\mathrm{a}}$ & $82.3^{\mathrm{a}}$ & 1.03 \\
\hline Crude ash & 45.6 & 44.9 & 50.2 & 47.8 & 0.78 \\
\hline
\end{tabular}

${ }^{\mathrm{a}, \mathrm{b}}$ Mean within the same row with no common superscripts differ significantly $(\mathrm{P}<0.05)$. 
Smith, 1985) 한편, 대사과정에서 생성되는 amylase, lipase 및 phytase 등 다양한 효소들이 숙주동물의 영양소 소화 및 흡수에 긍정적인 영향을 미칠 수 있다(Barnes와 Impey, 1972; Champ 등, 1983). 또한 E. coli 및 Salmonella와 같은 유해균의 성장을 억제하는 한편 유익균의 증식 및 서식에 긍정적인 영향을 미쳐 장관 상 피세포 및 융모 발달을 향상시킨다고 알려져 있다(Fuller, 1989; Jin 등, 1996; Prins, 1977). 본 연구에서도 이와 같은 작용에 의해 영양소 이 용율이 개선된 것으로 사료된다.

시험 3. 음수 내 유산균의 급여 빈도에 따른 육계 생산성 변화

(1) 육계 생산성

유산균의 급여 빈도에 따른 육계 생산성의 변화는 Table 5에 제시하였다. 5주 종료체중 및 증체량에 있어서는 유산균을 매일 또는 격일로 급여시 유의하게 증가하였다 $(\mathrm{P}<0.05)$. 사료섭취 량 및 사료요구율은 처리구간 차이가 없었다.

여러 연구에서 유산균 첨가 급여시 증체량
및 사료요구율 등 육계 생산성이 개선되었다고 보고하였으며 (Fuller, 1989; Jin 등, 1996; Watkins 등, 1982), 그 요인으로는 장내 환경 개선 및 경쟁적 배제를 통한 유해균 억제 및 유익균 증 가, 소장 상피세포 및 점막에 부착, 서식하면서 다양한 대사물질 분비, 점막 자극을 통한 장관 면역 및 융모 발달 등을 들 수 있다. 이를 위 해서는 유산균의 상피 세포 및 점막 부착 능력 은 필수적이다. 하지만 장관 내 외인성 유산균 의 부착 및 집락 형성에는 다양한 요인들의 영 향을 받는데, 숙주동물의 연령이 증가할수록 외인성 유산균이 집락을 형성하는데 어려움이 있다고 알려져 있다. 본 시험 결과 유산균을 매일 급여하는 것이 육계 생산성을 향상시키는 데 가장 효과적인 것으로 사료된다.

(2) 장내 미생물 균총 변화

유산균의 급여 빈도에 따른 장내 미생물 균 총 변화를 Table 6에 나타내었다. 회장과 맹장 내 유산균의 수는 유산균 급여시 전체적으로 증가하는 경향을 보였으며, 특히 매일 및 격일 급여시 유의하게 증가하였다 $(\mathrm{P}<0.05)$. Coliform

Table 5. Effects of feeding frequency of Lactobacillus on the growth performance in broiler chickens (Experiment 3)

\begin{tabular}{|c|c|c|c|c|c|c|}
\hline & \multirow{2}{*}{ Control } & \multicolumn{4}{|c|}{ Feeding frequency of Lactobacillus (intervals of day) } & \multirow{2}{*}{ SEM } \\
\hline & & 1 & 2 & 3 & 5 & \\
\hline Initial body weight (g) & 39.9 & 3935 & 39.7 & 39.2 & 39.9 & 0.11 \\
\hline Final body weight (g) & $1,824^{\mathrm{b}}$ & $1,871^{\mathrm{a}}$ & $1,867^{\mathrm{a}}$ & $1,847^{\mathrm{ab}}$ & $1,828^{\mathrm{b}}$ & 7.61 \\
\hline \multicolumn{7}{|l|}{ Body weight gain (g) } \\
\hline $0-21 d$ & 705 & 704 & 729 & 679 & 713 & 9.51 \\
\hline $22-35 d$ & $1,079^{\mathrm{b}}$ & $1,127^{\mathrm{a}}$ & $1,099^{\mathrm{ab}}$ & $1,129^{\mathrm{a}}$ & $1,075^{\mathrm{b}}$ & 8.86 \\
\hline $0-35 d$ & $1,784^{\mathrm{b}}$ & $1,831^{\mathrm{a}}$ & $1,828^{\mathrm{a}}$ & $1,808^{\mathrm{ab}}$ & $1,788^{\mathrm{b}}$ & 7.63 \\
\hline \multicolumn{7}{|l|}{ Feed intake (g) } \\
\hline $0-21 d$ & 987 & 977 & 1,032 & 946 & 991 & 15.47 \\
\hline $22-35 d$ & 1,935 & 1,917 & 1,953 & 1,852 & 1,911 & 16.69 \\
\hline $0-35 d$ & 2,922 & 2,894 & 2,986 & 2,798 & 2,902 & 30.34 \\
\hline \multicolumn{7}{|l|}{ Feed conversion ratio } \\
\hline $0-21 d$ & 1.40 & 1.39 & 1.42 & 1.39 & 1.39 & 0.01 \\
\hline $22-35 d$ & 1.80 & 1.70 & 1.78 & 1.64 & 1.78 & 0.03 \\
\hline $0-35 d$ & 1.64 & 1.58 & 1.63 & 1.55 & 1.62 & 0.02 \\
\hline
\end{tabular}

${ }^{\mathrm{a}, \mathrm{b}}$ Mean within the same row with no common superscripts differ significantly $(\mathrm{P}<0.05)$. 
Table 6. Effects of feeding frequency of Lactobacillus on the intestinal microflora in broiler chickens (Experiment 3)

\begin{tabular}{|c|c|c|c|c|c|c|}
\hline & \multirow{2}{*}{ Control } & \multicolumn{4}{|c|}{ Feeding frequency of Lactobacillus (intervals of day) } & \multirow{2}{*}{ SEM } \\
\hline & & 1 & 2 & 3 & 5 & \\
\hline \multicolumn{7}{|l|}{ Ileum } \\
\hline Lactic acid bacteria & $7.291^{\mathrm{b}}$ & $8.864^{\mathrm{a}}$ & $9.228^{\mathrm{a}}$ & $8.589^{\mathrm{ab}}$ & $7.265^{\mathrm{b}}$ & 0.13 \\
\hline Coliform bacteria & 5.168 & 5.984 & 6.100 & 5.697 & 5.567 & 0.15 \\
\hline Salmonella spp. & 5.267 & 5.698 & 5.987 & 5.124 & 5.268 & 0.19 \\
\hline \multicolumn{7}{|l|}{ Cecum } \\
\hline Lactic acid bacteria & $8.365^{\mathrm{b}}$ & $9.986^{\mathrm{a}}$ & $9.584^{\mathrm{a}}$ & $9.120^{\mathrm{ab}}$ & $9.368^{\mathrm{ab}}$ & 0.20 \\
\hline Coliform bacteria & 6.985 & 7.164 & 7.763 & 6.698 & 6.915 & 0.16 \\
\hline Salmonella spp. & 6.239 & 6.522 & 5.398 & 7.024 & 6.924 & 0.26 \\
\hline
\end{tabular}

a, b Mean within the same row with no common superscripts differ significantly $(\mathrm{P}<0.05)$.

bacteria 및 Salmonella 수에 있어서는 처리구간 차이가 없었다. 유산균은 가축의 장내에서 $E$. coli를 억제하며, Salmonella와 Campylobacter의 증식을 조절한다(Fuller, 1973; Dunham 등, 1993). Nurmi와 Rantala(1973)는 유산균은 영양 소 및 장관 부착 부위 등의 경쟁을 통해 병원 성 미생물의 집락 형성 및 증식을 저해한다고 보고하였다. 또한 유산균은 장내 미생물에 영 향을 미치는 여러 종류의 대사 물질을 생산하 는데 이 중 lactic acid는 장관 $\mathrm{pH}$ 를 낮추고, acetic acid 및 $\mathrm{H}_{2} \mathrm{O}_{2}$ 는 다른 미생물에 대한 독소 로 작용한다(White 등, 1969), acidophilin, reuterin, nicin 등과 같은 항생 물질 역시 생산한다고 보 고되었다(Tagg 등, 1976). 그러나 이러한 유산 균 및 그 배양물의 급여가 장내 미생물에 영향 을 미치지 못 하였다는 상이한 결과들도 보고 되어 왔다. Alder와 DaMass(1980)는 부화당일 유산균을 급여하였을 때 맹장 내 유산균 및 대 장균에 영향을 미치지 못 하였다고 보고하였으 며, Stavric 등 (1987) 역시 유산균 급여시 장관 내 Salmonella 수에 효과가 나타나지 않았다고 보고하였다. 본 연구를 통해 유산균의 음수 내 첨가 급여시 급여빈도별 차이는 있었으나 유산 균 첨가는 회장 및 맹장 내 유산균 수를 증가 시켜 $(\mathrm{P}<0.05)$ 장관 내 유산균의 집락 형성 및 서식을 증가시키는데 긍정적인 영향을 미치는 것을 확인할 수 있었다. 또한 유산균의 지속적 인 급여가 장관 미생물 균총 안정화에 효과적 인 것으로 판단된다.
IV. 요 약

본 시험은 외인성 유산균의 장내 생존성과 유산균 첨가수준 및 급여빈도가 육계 생산성에 미치는 영향을 조사함으로써 유산균의 적정 급 여방법을 구명하기 위하여 실시되었다.

시험 1 에서는 외인성 유산균의 장내 체류 시 간을 조사하기 위하여 5주령 육계 (Abor Acre) 100 수에서 사료 내 $1.0 \times 10^{4} \mathrm{cfu} / \mathrm{g}$ 수준으로 GFP 유전자가 도입된 유산균을 급여하였다. GFP 유 산균을 육계에게 급여한 결과 급여 3 일차까지 는 일정한 수 이상의 유산균이 관찰되었으나 그 이후 급격히 감소되는 것을 확인하였다.

시험 2에서는 유산균 적정 첨가 수준을 구명 하기 위하여 1일령 육계 수평아리 (Abor Acre) 480 수를 공시하여 4처리 4반복, 반복당 30수씩 임의 배치하여 5 주간 사양시험을 실시하였다. 시험처리는 항생제 무첨가구를 대조구로 하였 으며, 음수 내 유산균을 $5.0 \times 10 \mathrm{cfu} / \mathrm{mL}, 5.0 \times 10^{3}$ $\mathrm{cfu} / \mathrm{mL}$, 및 $5.0 \times 10^{5} \mathrm{cfu} / \mathrm{mL}$ 수준으로 첨가하여 유산균 처리구를 두었다. 5주 종료 체중은 $5.0 \times 10^{3} \mathrm{cfu} / \mathrm{mL}$ 첨가 급여시 $1,919 \mathrm{~g}$ 으로 가장 높았으며 $(\mathrm{P}<0.05)$, 증체량은 $5.0 \times 10^{3} \mathrm{cfu} / \mathrm{mL}$ 및 $5.0 \times 10^{5} \mathrm{cfu} / \mathrm{mL}$ 첨가 급여시 대조구에 비해 유 의하게 증가하였다 $(\mathrm{P}<0.05)$. 회장 및 맹장 내 유산균 수에 있어서는 첨가수준별로 차이는 있 었으나 유산균 첨가 급여시 회장 및 맹장 내 유산균 수가 유의하게 증가하였으며 $(\mathrm{P}<0.05)$, 그 변화 양상은 회장과 맹장에서 유사하게 나 
타났다. 단백질 및 지방 이용율이 유의하게 증 가하였다 $(\mathrm{P}<0.05)$, 건물 및 조회분에 있어서는 처리간 차이가 관찰되지 않았다.

시험 3에서는 유산균 적정 급여 빈도를 구명 하기 위하여 1 일령 육계 수평아리 (Abor Acre) 600 수를 공시하여 5처리 4반복, 반복당 30수씩 임의 배치하여 5 주간 사양시험을 실시하였다. 시험처리는 항생제 무첨가구를 대조구로 하였 으며, 유산균이 $5.0 \times 10^{3} \mathrm{cfu} / \mathrm{mL}$ 수준으로 첨가된 음수를 1 일, 2일, 3일 및 5일 간격으로 급여한 유산균 처리구를 두었다. 5주 종료체중 및 증 체량에 있어서 유산균을 매일 또는 격일로 급 여시 유의하게 증가하였다 $(\mathrm{P}<0.05)$. 사료섭취량 및 사료요구율은 처리구간 차이가 없었다. 회 장과 맹장내 유산균의 수는 유산균 급여시 전 체적으로 증가하는 경향을 보였으며, 특히 매 일 및 격일 급여시 유의하게 증가하였다 $(\mathrm{P}<$ 0.05). Coliform bacteria 및 Salmonella 수에 있 어서는 처리구간 차이가 없었다.

본 시험 결과, 유산균의 음수 내 첨가 급여 는 육계 생산성 및 장내 미생물 균총에 긍정적 인 영향을 미쳤으며, 유산균의 적정 첨가 수준 은 음수 $1 \mathrm{ml}$ 당 유산균 $5.0 \times 10^{3} \mathrm{cfu}$ 이었으며, 급여 빈도에 있어서는 매일 급여하는 것이 효 과적인 것으로 판단된다.

(색인어 : 유산균, 육계, 생산성, 영양소 이용율, 장내 미생물 균총)

\section{V. 인 용 문 헌}

1. AOAC. 1995. Official method of analysis, 16th edition. Association of Official Analytical Chemists. Washington. D. C.

2. Adler, H. E. and DaMass, A. J. 1980. Effect of ingested Lactobacilli on Salmonella infantis and Escherichia coli and on intestinal flora pasted vents and chick growth. Avian Dis. 24:868-878.

3. Barnes, E. M. and Impey, C. S. 1974. The occurrence and properties of uric acid decomposing anaerobic bacteria in the avian cecum. J. Appl. Bacteriol. 37:393-409.

4. Bongaerts, G., Severijne, R. and Timmerman, H. 2005. Effect of antibiotics, prebiotics and probiotics in treatment for hepatic encephalopathy. Med. Hypotheses. 64:64-68.

5. Champ, M., Szylit, O., Raibaud, P. and AitAbdelkader, N. 1983. Amylase production by three Lactobacillus strains isolated from chicken crop. J. Appl. Bacteriol. 55:487.

6. Duncan, D. B. 1955. Multiple range and multiple F test. Biometric. 11:1-42.

7. Dunham, H. J., William, C., Edens, F. W. Casas, I. A. and Dobrogosz, W. J. 1993. Lactobacillus reuteri immunomodulation of stressor-associated disease in newly hatched chickens and turkeys. Poult. Sci. 72(Suppl 1):103(abstract).

8. Fuller, R. 1973. Ecological studies on the Lactobacillus flora associated with the crop epithelium of the fowl. J. Appl. Bacteriol. 36:131139.

9. Fuller, R. 1975. Nature of the determinant responsible for the adhesion of Lactobacilli to chicken crop epithelial cells. Fournal of General Microbiology. 87:245-25.

10. Fuller, R. 1977. The importance of Lactobacilli in maintaining normal microbial balance in crop. $\mathrm{Br}$. Poult. Sci. 18:85-94.

11. Fuller, R. 1989. Probiotics in man and animals. J. Appl. Bacteriol. 66:365-378.

12. Gibson, G. R. and Fuller, R. 2000. Aspects of in vitro and in vivo research approaches directed toward identifying probiotics and prebiotics for human use. J. Nutr. 130:391-395.

13. Gilliland, S. E. 1979. Beneficial interrelationships between certain micro-organisms and humans: Candidate micro-organisms for use as dietary adjuncts. J. Food Protect. 42:164.

14. Impey, C. S. and Mead, G. C. 1989. Fate of Salmonellasin the alimentary tract of chicks pre-treated with a mature caecal microflora to increase colonization resistance. J. Appl. Bacteriol. 66:469.15. Jin L. Z., Ho, Y. W., Abdullah, N. and Jalaudin, S. 1996. Influence of dried Bacillus subtillis and Lactobacilli cultures on intestinal microflora and performance in broilers. Asian-Australian J. Anim. Sci. 9:397-403.

16. Jin, L. Z., Ho, Y. W., Abdullah, N., Ali, M. A. 
and Jalaudin, S. 1998. Growth performance intestinal microbial populations and serum cholesterol of broilers fed diets containing Lactobacillus cultures. Poult. Sci. 77:1259-1265.

17. Lyons, T. P. 1987. Probiotics: an alternative to antibiotics. Pig News Info. 8:157-164.

18. Maiolino, R., Fioretti, A., Menna, L. F. and Meo, C. 1992. Research on the efficiency of Mohan, B., Kadirvel, R., Natarajan, A. and Bhaskaran, M. 1996. Effect of probiotic supplementation on growth nitrogen utilization and serum cholesterol in broilers. Br. Poult. Sci. 37:395-401.

19. Mohan, B., Kadirvel, R., Natarajan, A. and Bhaskaran, M. 1996. Effect of probiotic supplementation on growth nitrogen utilization and serum cholesterol in broilers. Br. Poult. Sci. 37: 395-401.

20. Nahashon, S. N., Nakaue, H. S., Snyder, S. P. and Mirosh, L. W. 1994. Performance of single Comb white Leghorn layers fed corn-soybean meal and barley-corn-soybean meal diets supplemented with a direct fed microbial. Poult. Sci. 73:1712-1723.

21. NRC. 1994. Nutrient requirement of poultry. National Research Council National Academy of Science Washington DC.

22. Nurmi, E. and Rantala, M. 1973. New aspects of Salmonella infection in broiler production. Nature. 241:210-211.

23. Pirgozliev, V., Oduguwa, O., Acamovic, T. and Bedford, M. R. 2007. Effect of diets containing Esherichia coli-derived phytase to young chickens and turkeys: effects on performance, metabolisable energy, endogenous secretions and intestinal morphology. Poult. Sci. 86:705-713.

24. Prins, R. A. 1977. Biochemical activities of gut micro-organisms. In: Clarke, R., T., J. and Bauchop, T. eds. Microbial Ecology of the Gut. p73-183. London. Academic press.

25. SAS. 2002 SAS/STAT Software for PC. Release 9.1, SAS Institute Inc. Cary, NC, USA.

26. Smith, M. W. 1985. Expression of digestive and absorptive function in differentiating enterocytes. Annu. Rev. Physiol. 47:247.

27. Schneitz, C., Kiiskinen, T., Toivonen, V. and Näsi, M. 1998. Effect of BROILACT ${ }^{\circledR}$ on the physicochemical conditions and nutrient digestibility in the gastrointestinal tract of broilers. Poult. Sci. 77:426-432.

28. Stavric, S., Cleeson, T. M., Blanchfield, B. and Pivnick, H. 1987. Role of adhering microflora in competitive exclusion of Salmonella from young chicks. J. Food Protect. 50:928.

29. Tagg, J. R., Dajani, A. S. and Wannamaker, L. W. 1976. Bacteriocins of gram-positive bacteria. Bacteriological Reviews 40:722-756.

30. Watkins, B. A., Miller, B. F. and Neil, D. H. 1982. In vivo effects of Lactobacillus acidophilus against pathogenic Escherichia coli in gnotobiotic chicks. Poult. Sci. 61:1298-1308.

31. Watkins, B. A. and Kratzer, F. H. 1983. Effect of oral dosing of Lactobacillus strains on gut colonization and liver biotin in broiler chicks. Poult. Sci. 62:2088-2094.

32. White, F., Wenham, G., Sharman, G. A., Jones, A. S., Rattray, E. A. and McDonald, I. 1969. Stomach function in relation to a scour syndrome in the piglet. Br. J. Nutr. 23:847-58.

33. Yeo, J. and Kim, K. 1997. Effect of feeding diets containing an antibiotic, a probiotic, or Yucca extract on growth and intestinal urease activity in broiler chicks. Poult. Sci. 76:381-385.

34. 김상호, 박수영, 유동조, 나재천, 최철한, 박용윤, 이상진, 류경선. 2000. 육계 생산성 및 맹장내 미 생물에 대한 유산균의 첨가 효과. 한국가금학회 지. 27:37-41.

35. 김세헌, 유승권, 오세종, 한경식, 김영훈. 2006. 락토바실러스 균종을 위한 형질전환 방법 및 외 래 단백질 발현 백터. 등록번호 10-0635450.

36. 박수영, 김상호, 유동조, 이상진, 류경선. 2001. 유산균의 급여가 육계의 성장능력에 미치는 영 향. 한국가금학회지 28(1):27-40.

(접수일자 : 2008. 8. 28. / 수정일자 : 2008. 10. 31./ 채택일자 : 2008. 11. 20.) 